\title{
DNACPR notices: campaigner for patients' right to be consulted says government has misunderstood her demands
}

\section{Clare Dyer}

The BMJ

A campaigner for the rights of patients to be consulted before a "do not attempt cardiopulmonary resuscitation" (DNACPR) notice is placed in their medical notes has reiterated her threat to take legal action if necessary, after accusing the UK government of "misunderstanding" her demands.

Kate Masters is the daughter of David Tracey, who brought a successful legal action to establish patients' right to be consulted after a doctor put a DNACPR notice in his terminally ill wife's records without informing her. The Court of Appeal ruled in 2014 that University Hospitals Cambridge NHS Foundation Trust had violated her right under article 8 of the European Convention on Human Rights - the right to privacy — in failing to involve her in the process.

On 6 May, Masters sent a letter before action to Matt Hancock, health and social care secretary for England, asking him to use emergency powers to create a national policy on the issue. ${ }^{1}$ She said she had become concerned that, during the covid-19 pandemic, doctors were placing blanket DNACPR notices in patients' records without their knowledge and against the law.
She told Hancock that she was worried about her own position, since she has ongoing health problems, and was afraid that family members with serious medical conditions were also at significant risk of decisions being taken without proper process. But government lawyers replied that individual decisions were not a matter for the health secretary and claimed that differences in approach were down to inconsistent decision making rather than, as Masters had argued, a systematic breach of article 8 .

In her second pre-action letter, Masters says she believes that the rights of patients under article 8 are being systematically violated as a result of the health secretary's delegation of resuscitation policies to a local level at a time of a national health emergency.

1 Dyer C. Covid-19: Campaigner calls for national guidance to stop DNR orders being made without discussion with patients and families. BMJ 2020;369:m1856 10.1136/bmj.m1856 32381552

Published by the BMJ Publishing Group Limited. For permission to use (where not already granted under a licence) please go to http://group.bmj.com/group/rights-licensing/ permissions 